\author{
Olesea Bodean-Vozian \\ Moldova State University, Moldova \\ Cornelia Cincilei \\ Moldova State University, Moldova
}

\title{
ENCODING PATH IN MOTION EVENTS: BOUNDARY-CROSSING AS A RELEVANT TYPOLOGICAL CRITERION
}

\begin{abstract}
Summary. Talmy's $(1975,1985,1991,2000)$ seminal work on motion events representation in languages that led to significant typological distinctions is primarily based on the differences in encoding (framing) of the Path, as one of the basic semantic components of such events, either in the V(erb stem) or in the S(atellite) - which accounts for the proposed typological language dichotomy $\mathrm{V}$-framed (VLS) and S-framed languages (SLs). Although the above distinction is a very important one, having implications at the level of syntactic structure, crosslinguistic data indicate to some variations that further prompted researchers to question a clear-cut binary typological opposition. Thus, more thorough data from Romance languages (in addition to Spanish, French and Italian) led to re-considering their status as VLs and rather considering them belonging to the third class of "split" languages (Talmy). The aim of the paper is to analyze the place of Romanian in this typological classification, through making observation on the Path representation in motion events in contrasted narrative texts translated from English (a SL) into Romanian. The hypothesis is that Romanian might claim a mixed typological status, eventually belonging to the class of "split" languages based on the assumption that, first, it is not so poor in manner of motion verbs ( $\mathrm{MmV}$ ) as it is presumably the case of VLs (see the alternative labels sometimes attached to SLS vs. VLS, respectively - manner-rich vs. manner-poor languages) and, second, it does not exclude the possibility of using complex Path as satellite to a MmV, particularly boundary-crossing, which can serve as a test to determine the typological class of language (e.g., a țâșnit de după perdea (lit. rushed from behind the curtain) - 'rushed out from behind the curtain'; a lunecat de pe acoperiș (lit. slipped from on the roof) - 'slipped from the roof'. In this respect, the paper aims at focusing on the nature of the second preposition.
\end{abstract}

Keywords: typology, motion events, boundary-crossing, Manner verbs, Path verbs, English, Romanian.

\section{Overview}

Humans explore the world by moving in it, whether moving their whole body as during walking or driving a car, or moving their arm to explore the immediate environment (Wutte, 2012). Languages differ in the way they conceptualize the motion, a phenomenon that linguists have paid a special attention to. Thus, an array of cross-linguistic research has been devoted to motion expression in the last decades, Leonard Talmy's seminal work in typology (1978, 1985, 1991, and 2000) having a great contribution to it. Motion means change along a Path and this 
change represents the core of a motion event, which makes it different from other types of events in the language.

The present work is concerned with the translation difficulties resulting from the different ways Path and Manner are encoded by two typologically distinct languages, in Talmy's (2000) parlance, English and Romanian, with a special focus on the boundary-crossing phenomenon, which is considered by some authors (Aske, 1989; Slobin, 1994, 1997) as one of the reliable typological criteria supporting that distinction. The data collected from parallel English and Romanian narrative texts also help us clarify the typological status of Romanian, attributed a priori, as a Romance language to the verb-framed class.

\section{From Lexicalisation Patterns to Motion Events}

The typological differences related to the way motion is expressed in languages have been largely investigated in the past decades, particularly under the influence of new approaches in the framework of cognitive linguistics targeted at understanding the mechanisms of conceptualization of certain phenomena by various languages.

According to Talmy $(1985,1991)$, the concept of a motion event includes central or internal components, on the one hand - Figure (the moving entity), Ground (the spatial reference the Figure is translocating in respect to), Motion (change of location), and Path followed by the moving Figure - and associated external or secondary components, on the other hand - Manner (the way the Figure moves) and Cause (what made the Figure move). The Path includes the Source, the Trajectory and the Goal and is viewed as the core component of a motion. Talmy (1985) distinguishes between two different ways (patterns) of Path lexicalization, which constitute the base for the typological distinction between Verb-framed languages and Satellite-framed languages. As stated by Talmy (1991, 2000), the former typically incorporate the information on the Path of motion into the verb (like in Romance Languages), while the latter typically leave it out of the verb and convey it in a satellite (like in Germanic Languages). These typological differences are illustrated by the Romanian and English examples, respectively:

(1) Trăsurile se depărtară.

Lit. 'The carriages distanced themselves.' Carriages rolled away. 
In the last decade, Talmy's typology has drawn considerable interest and was repeatedly revisited. Along with the new developments in cognitive linguistics, a shifting focus of typological studies on motion conceptualization can be attested: from lexicalization patterns to lexico-grammatical patterns and further towards the broader context that would reflect different patterns of conflation of motion frame elements, of their explicitation or implicitation preferences by various languages, of relevant factors influencing these preferences, etc.

Without denying the importance of Talmy's typology, several questions were asked by researches regarding the VLs and SLs dichotomy, which helped deepen the investigation of the motion events as a complex phenomenon. Thus, some critics questioned the way Talmy defined the notion of "satellite" and stressed the need for another approach to satellites and prepositions (Filipović, 2007; Croft, 2010). Other authors such as Slobin and Bohnemeyer (2004; 2007) emphasized the need of considering languages that do not fit into Talmy's binary typology, the so-called equipollently-framed languages, thus suggesting a threemember typology (i.e. languages of Type I, II, and III).

The arguments invoked above do not seem to overturn Talmy's typology, but rather prove the typological relevance of the opposed conceptualization patterns. Still, like in the case of many typological classifications, one can rarely find natural languages of pure types and it might be more appropriate to speak about dominant types of patterns in a certain language.

In confirmation of this, researchers have lately wondered whether one could talk about intra-typological variation in genetically related languages such as Romance languages or Germanic languages, stating that "Languages vary in the degree of detailed description with respect to the semantic components in a given event independently from the lexicalisation pattern they belong to" (IbarretxeAntuñano \& Hijazo-Gascón, 2012, p. 6) as well as diatopic variations (Berthele, 2004) in one and the same language according to geographical area (Romance languages [Italian; Spanish], Germanic languages [English; German]).

\section{Typological Variations in Encoding Manner and Path, and Translation Difficulties}

One of the difficulties a translator encounters when translating from a language of one type into a language of another type is related to the different ways of 
encoding Manner, an associated element of the motion event. Languages that consider it as a salient element, like for instance, English, conflate Manner in the verb of motion, producing in consequence a rich class of Manner-of-motion verbs. Other languages, such as Romanian, rather explicitate Manner through nonfinite verb forms or adverbial constructions, or leave it out to the context. From the above perspective, an alternative name for the two types of languages is the following: Manner-rich or high-Manner languages (Hi:M-languages) for SLs and, respectively, Manner-poor or low-Manner languages (Lo:M-languages) for VLs.

Slobin (2004) suggested a Manner salience cline in relation to the explicitness of the information on Manner of motion instead, and the cline is based on languages with rich and limited means to render Manner. Recent studies have proven, however, that this richness/poorness does not depend on the lexicalisation pattern, because there are languages that belong to VLs type and can be highManner languages. As a rule, Manner can refer to various aspects (Slobin, 2004) which are found both in SLs and in VLs: motor pattern (ran after - se luară alergând [lit. 'started running']), rate of motion (marched on - îşi continuară drumul [lit. 'they continued their way']), speed (turned quickly - se răsuci fulgerător [lit. 'he turned like wildfire']), means of transport (they rode - au pornit călare [lit. 'they were off riding']), medium (the wind flowed down - Un vânt năvăli [lit. 'the wind stormed']), degree of efforts (dragged from under trase de sub [lit. 'pulled from under']), character's state/spirit (jumped with surprise - sări speriat [lit. 'jumped scared']), attitude (stray about - porniră furișindu-se [lit. 'they were off creeping']) and any evaluative factors that might be involved with the movement (slipped out of - se furişă afară [lit. 'they crept outside']).

It has been noted that English speakers have the possibility to choose from a vast and expressive range of manner-of-motion verbs, the class which is enriched due to conversion, especially metaphor-based conversion, like in (3) $\mathrm{He}$ ducked too late. Such verbs can be combined with a remarkable collection of directional satellites: wander off, run downhill, climb up, stumble forward, fly up, etc. English speakers have the opportunity to render nuances of evaluation and subjective description, the language paying much attention to assessing or evaluating the attitude of the moving Figure (Slobin, 2014). By conflating the Manner component of motion in the root of the verb and leaving the Path outside, 
to the satellite, English uses the language economy principle. Slobin (2006, p. 62) calls this principle "a low cost alternative".

Romanian encodes Motion with Path, leaving the Manner to be either omitted: (4) de data asta, pe capră se afla un singur căruţaş bătrân [lit. 'this time, on the box-wood there was one old waggoner' (an old man was driving it all alone)] or be expressed in subordinate elements such as gerunds and adverbs: (5) ieși fuguța [lit. 'exited in a hurry' (trotted off)], (6) se luară alergând [lit. 'they were off running' (they ran)] (7) se îndreptă trecând [lit. 'he headed for by passing' (he walked through)], (8) se răsuci fulgerător [lit. 'he turned like wildfire' (he turned quickly)], (9) cobora cu repeziciune [lit. 'was climbing down quickly' (ran swiftly downwards)]. This typological distinction is becoming very relevant in the case of translating narrative texts from English into Romanian.

Slobin (1997, p. 459) suggested that SLs "seem to have a 'two-tiered' lexicon of Manner verbs: the neutral, everyday verbs - like walk, fly and climb, and the more expressive or exceptional verbs - like dash, swoop and scramble." These languages tend to considerably augment the second-tier, the expressive lexicon. The situation is different in Verb-framed languages that tend to have smaller lexicons of expressive Manner verbs, and they do not demonstrate a fine granularity similar to SLs.

Still, it will not be fair to consider that Romanian (like other Romance languages) lacks Manner-of-motion verbs. As mentioned by Pană Dindelegan (2013), from the typological perspective, Romanian verbs are both Path-encoding and Manner-encoding. Thus, the verbs do encode Motion and Manner, the speakers being able to use such constructions when expressing activity-type events ${ }^{29}$ : (10) Se târî pe sub mese până în colţul întunecos [lit. 'He dragged himself under tables up to the dark corner' (Frodo crawled away under the tables to the dark corner)], (11) El a sărit în apă [lit. 'He jumped into the water' (He leaped into the waters)], (12) Ar fi ţâşnit dintre copaci şi s-ar fi repezit în direcţia vocilor [lit. 'He would have sprang among trees and would have rushed in the direction of voices' (He would have burst out of the trees and dashed off towards the voices)], (13) Când a auzit vocile, a şters-o [lit. 'When he heard the voices, he

\footnotetext{
${ }^{29}$ According to Zeno Vendler's (1967) verb classification into states, activities, achievements and accomplishments. Activities are open-ended, atelic processes, such as run, jump, and walk, contrary to accomplishments, which are telic processes, or with an endpoint, such as John finished cutting the carrots.
} 
sneaked away' (As soon as he heard the voices he slipped away)], (14) Mărşăluiau de mai bine de o oră [lit. 'They were marching more than one hour' (They had been jogging along again for an hour)], etc.

In these examples, the English Manner-of-motion verbs were translated into Romanian through Manner-of-motion verbs. We could notice that Romanian added nuances of motor pattern, rate of motion, speed, and attitude. Aske (1989) suggested that in VLs, Manner-of-motion verbs are used with Path phrases if they are atelic: sticla a plutit spre peșteră (lit. 'the bottle floated towards the cave' [compare with the classical English example: 'the bottle floated into the cave'). In 1994, Slobin and Hoiting expanded Aske's proposal in relation to the use of Manner-of-motion verbs in VLs: the restriction of $\mathrm{MmV}$ used with Path phrases applies only to those events that involve movement across a boundary.

While investigating Spanish, Naigles and Terrazas (1998) further specified that as a VLs language, it uses Path verbs in horizontal boundary-crossing situations and Manner is conflated in the verb when vertically traversing the boundary. Therefore, Manner is allowed in VLs in cases when there are short Paths, punctual acts and vertical movements, especially in boundary-crossing.

When attempting to illustrate the intra-typological variation, the focus is also put on Path, which is viewed as the basic semantic component of a motion event, expressing the course that a Figure follows from Source to Goal. Compared to Manner, which is an optional element, Path is a mandatory category, since motion cannot occur in absence of Path, be it encoded in a verb or a satellite. It was noticed that Path and Motion are less conflated by SLs than the VLs. Although English is mostly encoding Path in satellites: go up, get out, dance about, hop through, etc., it has a series of verbs borrowed from Latin through French that inherently express Path, similar to Romanian motion verbs: exit (a ieși), enter (a intra), ascend (a urca), descend (a coborî). Alike the Manner cline proposed by Slobin (2004), Ibarretxe-Antuñano, who conducted a study on more than 20 languages (2004, 2009), discussed the existence of a Path-related cline in typological sense, while considering the size of the class of directional verbs and prepositions in different languages (these ranging from high-Path-salient to lowPath-salient). 


\section{Typological Variations in Encoding Complex Path}

Another significant typological difference with considerable implications for translation refers to the level of event granularity in expressing complex Paths. In such cases, there is a distinction between VLs and SLs in relation to the number of Path clauses or segments they attach to the verb used in a motion event. Romanian is not able to rely on the economical way of representing complex motion events similar to English, a $\mathrm{Hi}$ : M-language, which can use motion verbs with a series of directional satellites encoding Path for such purposes: dashed off towards, spread out across, thrust out and downwards, etc.

Studies have shown that when an English sentence with a single motion verb with complex Path is translated into VLs, the latter splits it into several clauses, each with its own verb and related preposition:

(15) a. He rode through the gate and up the lane towards the causeway like a bolt of thunder.

(16) a. He walked home under the early stars, through Hobbiton and up the hill.

(17) a. They went down the slope, and across the stream where it dived under the road, and up the next slope, and up and down another shoulder of the hills.

In such cases, Romanian needs to employ additional verbs to render the same Path, which make these sentences less dynamic and drier, if compared to the constructions from the original text:

(15) b. El a ieşit pe poartă ca fulgeru', dispărând pe drumeag spre drumu' principal [lit. 'He exited through the gate as a thunder, disappearing on the way to the main road'].

(16) b. Se îndreptă spre casă trecând prin Hobbiton și urcând Măgura [lit. 'He headed for the house, by passing through Hobbiton and by climbing the Hill'].

(17) b. Coborâră panta, trecură pârâul acolo unde acesta se ascundea sub drum, urcară povârnişul următor şi apoi coborâră iarăşi şi urcară la loc un alt colnic [lit. 'They climbed down the slope, passed the stream where it hid under the road, climbed up the slope and then climbed down and climber up another slope']. 
This occurs because VLs requires each change of Path to be expressed by a verb when the change is telic (Aske, 1989) or boundary-crossing (Slobin and Hoiting, 1994), or moving with relation to Earth's gravity (Talmy, 2000). Complex Paths are in overall mostly encountered in SLs, compared to VLs and this distinction becomes very salient in the case of narrative texts translation from English into Romanian, since it might have an impact on the stylistic colouring, the change in narrative perspective and tempo, etc.

In a 2010 study, Croft proposed the double framing construction in which the Path or the framing expression is conveyed twice, once as a detached satellite and once as part of the verb, like in the example: to go up above, to go down below, etc. This phenomenon can be found in Romanian as well: a intra înăuntru, a ridica sus, etc. Further investigation is needed to establish whether it is a pleonasm or rather a situation in which directional prepositions are used for context-specific purposes.

Narrative texts in principle lend themselves to a comparative study of Manner and Path encoding by typologically different languages. When analysing the English text, we noticed that more attention was devoted to the dynamics of the narrative, because motion verbs attached to satellites are available to describe Paths: (20) a. They went out into the hall. However, there are cases when the Romanian translation focuses less on Path description in favour of scene-setting and, therefore, the trajectories can be inferred: (20) b. Ieşiră în hol [lit. 'they exited in the hall']. Thus, the narrative description of the scene loses the dynamics of the original.

\section{The Boundary-Crossing Phenomenon}

In case of motion events, changes of state or crossing a threshold represent boundary-crossing (B-C) events. Aske in 1989 was the first to point out that Verbframed languages are restricted in the usage of the satellite-framed constructions for telic motion events, later called 'boundary-crossing' by Slobin (1997), but not for atelic motion events (Verkerk, 2013). The motion events that reveal the traversal of a spatial boundary are considered to be illustrative of the differences between two types of languages, since they can serve as a reliable test to detect the typological class of a language. 
The lexical elements encoding Path associated with boundary-crossing might be quite different, such as: horizontal vs. vertical; unidirectional vs. nonunidirectional; instantaneous vs. temporally extended; implicit vs. explicit; rapid vs. slow motion; movement from an open space into a confined space or vice versa; movement through a bounded space; movement over a line and movement from one medium into another.

For spatial boundary-crossing, V-language speakers, for example, use a Path verb to mark the change of location (Aske, 1989; Slobin and Hoiting, 1994) discarding the information on Manner (for V-language speakers, it can be a linguistically less salient aspect to encode when referring to crossing a spatial boundary):

(1) a. Întinse mâna afară şi o îndreptă în jos.

b. He thrust a long arm out and downwards.

(2) a. Râul Salcia ieşea din Pădure.

b. The Withywindle flowed out of the Forest.

S-language speakers (English) predominantly use Manner verbs in case of describing Manner of motion scenes involving boundary-crossing:

(3) a. Suddenly he hopped through the door.

b. Pe neaşteptate, se repezi spre uşă.

In S-framed languages such as English, the conflation between Motion and Manner can happen in boundary and non-boundary-crossing situations, while Vframed languages allow conflation only in non-boundary-crossing situations. And although example (3b) uses a Manner of motion verb, this is not a case of boundary traversal and it is an atelic construction, contrary to the English sentence. However, in a study carried out by Slobin (2004), the author pointed out that verbs which indicate instantaneous, punctual acts constitute an exception and they can occur with boundary-crossing in V-framed languages:

(4) a. El se prăvăli în apă.

b. He plunged into the water.

Speakers of V-framed languages never express the crossing of a boundary in a satellite (Fortis, 2010). 


\section{Methods}

\section{Data Collection and Analysis}

The current paper employed 25 examples of boundary-crossing events from the novel "The Lord of the Rings" (J. R. R. Tolkien) and their translated equivalents that were selected in order of appearance in the narrative text and were investigated based on specific categories. Thus, the examples were distributed by the number of motion event segments, verb type and lexical category.

\section{Number of B-C Events by Number of Segments}

We distributed the examples per number of segments contained in the motion expressions. Each event segment was represented by one clause in English and Romanian. In cases when nonfinite verb forms were employed in Romanian, there were two segments equalling to two clauses.

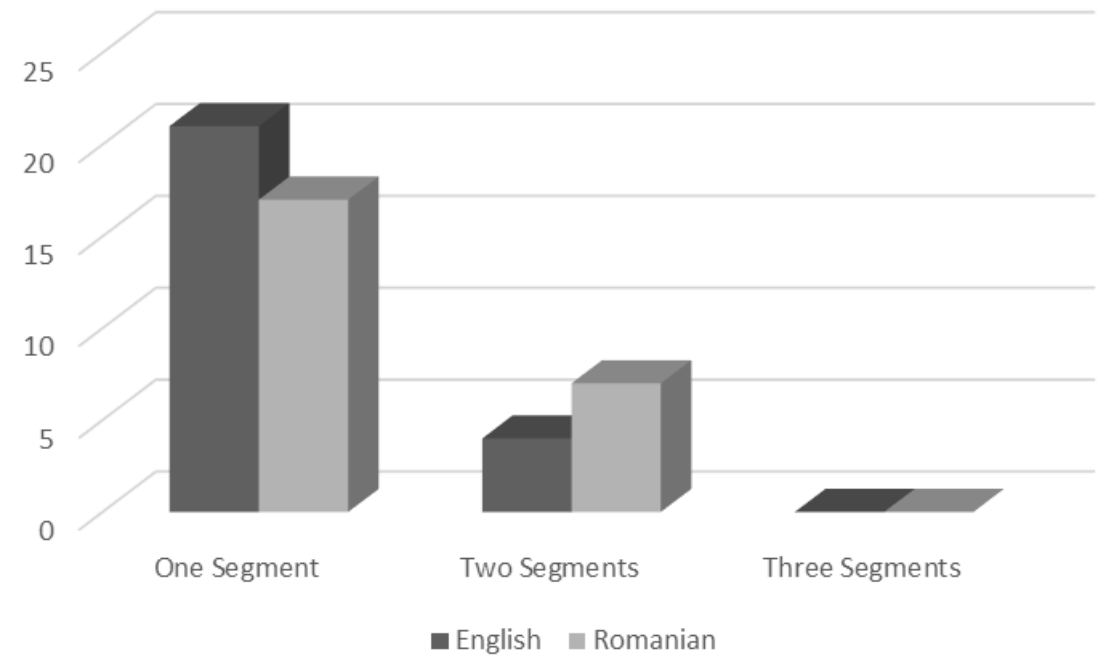

Fig. 1 Number of Event Segments

As shown in Fig.1, the English text almost entirely (84\%) relied on boundarycrossing descriptions with a single segment (21 out of 25 events), as in the following example: (5) Frodo sprang out of the waggon, followed by 4 twosegment events (16\%) out of 25: (6) Sam gripped him by the jacket, and 
dragged him from under the root. No boundary-crossing events that would employ three segments were encountered. The Romanian translation produced 17 boundary-crossing descriptions with one segment (68\%) as in: El a sărit în apă and 7 with two segments (28\%), as in the next example: O căruţă străbătu satul Lângă Ape, venind dinspre Podul Viniac. Therefore, both languages predominantly use single clauses ( 1 segment) to describe the same boundary-crossing events (classical condensed method to encode Manner and Path). In Romanian, 1 clause out of 25 comprised a verbal phrase instead of a motion verb. Hence, there are differences in event segmentation that are important for the typological distinction between languages. The English narrative produced more boundary-crossing descriptions with single segments than did the Romanian translation. The Romanian text generated more boundary-crossing descriptions with two segments when compared to the English text.

\section{Verb Choice in Source Text and Target Text}

The examples were divided into the following categories, based on the type of verb:
a) Manner Verbs of Motion
b) Path Verbs of Motion
c) Path+ subordinate (Manner)

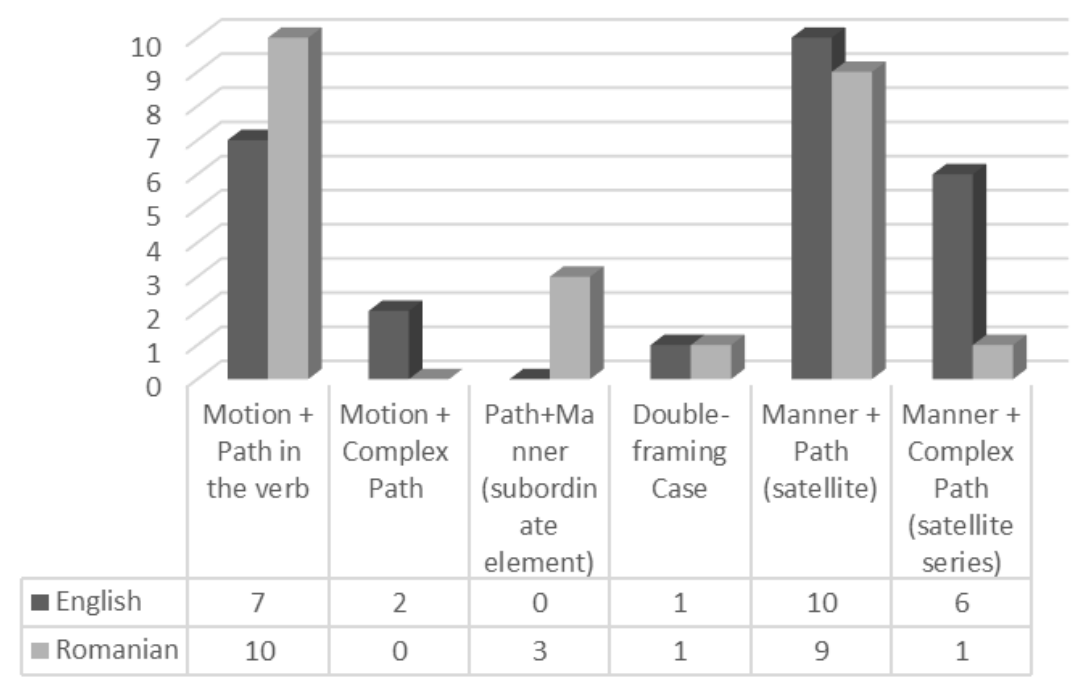

Fig. 2 Verb Conflation 
The majority of boundary-crossing events in English were of SLs type. As it is shown in Fig. 2, in the English corpus, there were 10 out of 25 [40\%] Manner Verb + Path (satellite) constructions and 6 out of 25 [24\%] constructions with Manner Verb + Complex Path (series of satellites). Examples of the opposite type are few, and mostly comprise Latinized motion verbs that inherently express Path, similar to Romanian motion verbs. Therefore, 7 out of 25 [28\%] were the examples comprising Motion + Path and 1 construction out of 25 [4\%] represents Motion + Complex Path. In Romanian, the following has been established: there were 10 out of 25 constructions [40\%] that convey Motion + Path in the root Verb, in 3 out of 25 constructions [12\%], Path Verb was accompanied by Manner nonfinite verb forms/adverbs; Manner Verb + Path satellite was encountered in 9 out of 25 cases [36\%], while Manner Verb + Complex Path satellite represented only 1 case out of 25 [4\%]. Although the number of cases with Manner verb + satellite (simple/complex Path) is $40 \%$ in Romanian, still the percentage of cases corresponding to VLs encoding type is almost 60\%. Nevertheless, the number of examples that were collected for this paper is not yet relevant in order to issue a substantial conclusion for the language.

\section{Lexical Categories}

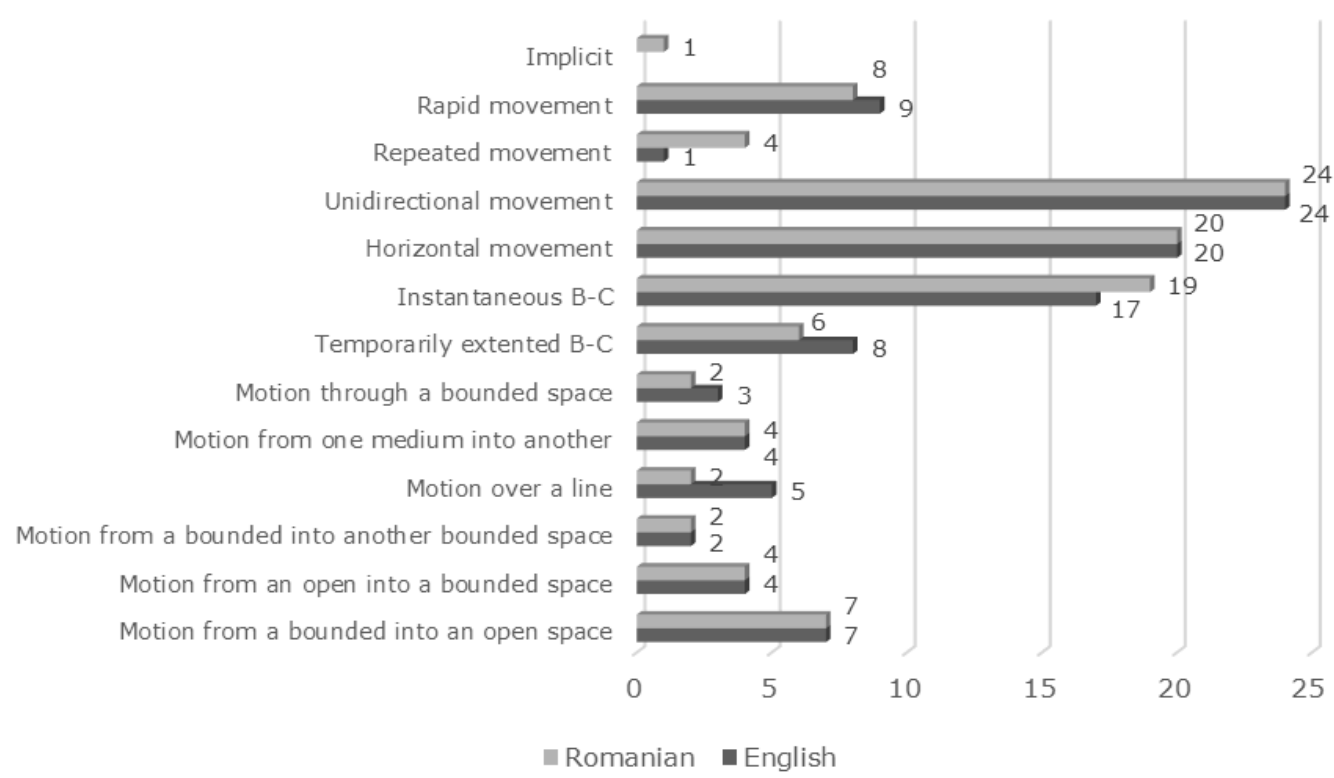

Fig. 3 Lexical Components 
We then examined the lexical components (Fig. 3) chosen by the author and translator for respective motion events. In the majority of cases, their number in both languages is similar, exception being those cases when the Romanian translator used Manner of motion verbs in a context where repeated or instantaneous events were involved. English relied predominantly on Manner verbs that were employed in events that showed some variation from Romanian, like the ones with motion over a line, motion through a closed space or temporarily extended boundary-crossing.

\section{Conclusions}

The boundary-crossing phenomenon is typologically relevant and the investigation showed that the Romanian translator adjusted to the requirements of the boundary-crossing constraint when conveying motion events from English, a Manner salient language. In the Romanian examples that were analysed, the group of Manner verbs was not so small and our evidence preliminarily suggests that there is not such a considerable difference between the two languages. An exception from the above-mentioned constraint is the fact that Manner and Motion conflation can happen in Romanian boundary-crossing events only when they involve rapid, punctual, and instantaneous motion.

Both languages express Path information, however, English displayed more constructions with Manner verb and complex Paths, compared to Romanian, where such constructions are also possible, but statistically they are not so numerous. In summary, although Talmy's theory is relevant and has implications, we cannot speak of a strict dichotomous distinction between the two languages and, certainly, it is not the case of two opposite poles.

The study confirmed that Romanian is not a pure type of language, but rather a split one, being similar to other Romance languages. This fact supports the hypotheses of other researchers (Slobin, 2004; Folli and Ramchand, 2005; Pavlenko and Volynsky, 2015; Hendriks and Hickmann, 2015) who have stated that there is no typological purism and that Talmy's dichotomy should be extended. A deeper investigation into the boundary-crossing could also impact current and future translators, who will understand this phenomenon better and will learn how to build their linguistic capacities in capturing various dimensions of 
this type of Path component and convey the richness of the English language (culture and narrative style) into their mother tongue.

\section{References}

Aske, J. (1989). Path predicates in English and Spanish: A closer look. Paper presented at the $15^{\text {th }}$ Annual Meeting of the Berkeley Linguistics Society, University of California, Berkeley.

Berthele, R. (2004). The typology of motion and posture verbs: A variationist account. In B. Kortmann (Ed.), Dialectology Meets Typology (pp. 93-126). Berlin: Mouton de Gruyter.

Bohnemeyer, J., et al. (2007). Principles of event representation in language: the case of motion events. Language, 83(3), 495-532.

Croft, W., et al. (2010). Revising Talmy's typological classification of complex events. In H. Boas (Ed.), Contrastive construction grammar (pp. 201-236). Amsterdam: John Benjamins.

Filipovic, L. (2007). Talking about Motion: A Crosslingual Investigation of Lexicalization Patterns. Amsterdam: John Benjamins.

Folli, R., \& Ramchand, G. (2005). Prepositions and Results in Italian and English: An Analysis from Event Decomposition. In H. Verkuyl, H. De Swart \& A. van Hout (Eds.), Perspectives on Aspect (pp. 81-105). Dordrecht: Kluwer Academic Publishers.

Fortis, J-M. (2010). The Typology of Motion Events. Space in Language. Retrieved from: http://htl.linguist.univ-paris-diderot.fr/fortis/leipzig/3.MOTION\%20 EVENTS.pdf.

Hendriks, H., \& Hickmann, M. (2015). Finding One's Path Into Another Language: On the Expression of Boundary Crossing by English Learners of French. The Modern Language Journal, 99, 14-31. doi: 10.1111/j.15404781.2015.12176.x.

Ibarretxe-Antunano, I. (2004). Motion events in Basque narratives. In S. Stromqvist \& L. Verhoeven (Eds.), Relating events in narrative: Vol. 2. Typological and contextual perspectives (pp. 89-112). Mahwah, NJ: Erlbaum.

Ibarretxe-Antunano, I. (2009). Path salience in motion events. In J. Guo, E. Lieven, S. Ervin-Tripp, N. Budwig, K. Nakamura \& S. Özçalışkan (Eds.), 
Cross-linguistic approaches to the psychology of language: Research in the tradition of Dan Isaac Slobin (pp. 403-414). New York: Psychology Press.

Ibarretxe-Antunano, I., \& Hijazo-Gascón, A. (2012). Variation in motion events. Theory and applications. In Space and Time in Languages and Cultures. Linguistic diversity (pp. 349-372). John Benjamin Publishing Company. DOI: $10.1075 /$ hcp.36.19iba.

Naigles, L., \& Terrazas, P. (1998). Motion verb generalizations in English and Spanish: Influences of language and syntax. Psychological Science, 9, 363-369.

Pană Dindelegan, G. (2013). The Grammar of Romanian. Oxford University Press.

Pavlenko, A, \& Volynsky, M. (2015). Motion Encoding in Russian and English: Moving Beyond Talmy's Typology. The Modern Language Journal, 99, 3248. DOI: $10.1111 / \operatorname{modl} .12177$.

Slobin, D. I., \& Hoiting N. (1994). Reference to movement in spoken and signed languages: Typological considerations. Paper presented at the $20^{\text {th }}$ Annual Meeting of the Berkeley Linguistics Society, University of California, Berkeley.

Slobin, D. I. (1997). Mind, code, and text. In Joan Bybee, John Haiman \& Sandra A. Thompson (eds.), Essays on Language Function and Language Type: Dedicated to T. Givón (pp. 437-467). Amsterdam: John Benjamins.

Slobin, D. I. (2004). The many ways to search for a frog: Linguistic typology and the expression of motion events. In S. Stromqvist \& L.Verhoeven (Eds.), Relating events in narrative: Typological and contextual perspectives (pp. 219-257). Mahwah, NJ: Erlbaum.

Slobin, D. I. (2006). What makes manner of motion salient? Explorations in linguistic typology, discourse, and cognition. In M. Hickmann \& S. Robert (Eds.), Space in languages: Linguistic systems and cognitive categories (pp. 59-81). Amsterdam/Philadelphia: John Benjamins.

Slobin, D. I. (2014). Manners of human gait: A crosslinguistic event-naming study. Cognitive Linguistics, 25(4), 701-741. De Gruyter Mouton.

Talmy, L. (1978). Figure and Ground in complex sentences. In H. Greenberg, A. Ferguson \& A. Moravcsik (Eds.) Universals of human language. Stanford University. 
Talmy, L. (1985). Lexicalization patterns: Semantic structure in lexical forms. In T. Shopen (Ed.), Language Typology and Lexical Description: Vol. 3. Grammatical Categories and the Lexicon (pp. 36-149). Cambridge: CUP.

Talmy, L. (1991). Path to realization: A typology of event conflation. Proceedings of the Berkeley Linguistics Society, 17, 480-519.

Talmy, L. (2000). Toward a Cognitive Semantics (Vol. I/II). Cambridge, MA: MIT.

Tolkien, J. R. R. (1954, 1955). The Lord of the Rings. London: Allen and Unwin. [Romanian transl. Irina Horea, Ion Horea, Gabriela Nedelea (2010). Stăpânul inelelor. București: Adevărul Holding].

Vendler, Z. (1967). Verbs and Times. In Z. Vendler (Ed.), Linguistics in Philosophy, Chapter 4 (pp. 97-121). Ithaca, NY: Cornell University Press.

Verkerk, A. (2013). Scramble, Scurry and Dash: The Correlation between Motion Event Encoding and Manner Verb Lexicon Size in Indo-European, Language Dynamics and Change, 3, 169-217.

Wutte, M. (2012). Understanding space by moving through it: Neural networks of motion- and space processing in humans. (Unpublished doctoral dissertation). Ludwig-Maximilians-Universität, München. 
Olesea Bodean-Vozian

Moldovos valstybinis universitetas, Moldova; oleseabodean@yahoo.com

Cornelia Cincilei

Moldovos valstybinis universitetas, Moldova; ccincilei@gmail.com

\section{KELIO SAZVOKOS UŽKODAVIMAS JUDĖJIMO PROCESE: RIBOS PERŽENGIMAS, KAIP SVARBUS TIPOLOGINIS KRITERIJUS}

Santrauka. Originalūs Talmy $(1975,1985,1991,2000)$ darbai apie judèjimo perteikima kalboje, kurie leido išryškinti reikšmingus tipologinius skirtumus tarp kalbu, pirmiausia pagristi kelio, kaip vieno pagrindinio tokiu kompleksiniu ivykiu komponento, savokos užkodavimo (irèminimo) skirtumus - ar pagrindinè judejjima reiškianti mintis užkoduota veiksmažodžio šaknimi $(\mathrm{V})$ ar satelitu (S). Tai paaiškina ir pasiūlyta veiksmažodžio ireeminimo (VLs) ir satelito ireminimo (SLs) kalbu tipologinę dichotomija. Nors šis savitumas labai svarbus ir prasmingas sintaksiniame struktūriniame lygmenyje, tarpkalbiniai duomenys atspindi tam tikrus skirtumus, dèl kuriu tyrèjai èmè abejoti aiškia dvinare tipologine priešprieša. Taigi išsamesni romanu kalbu (kartu su ispanu, prancūzu ir italu kalbomis) duomenys leido šias kalbas priskirti trečiai - "išskaidytu" - kalbu kategorijai, o ne VLs tipo kalboms. Šio tyrimo tikslas - apibrěžti rumunu kalbos vieta nagrinèjamoje tipologineje klasifikacijoje, kartu atliekant kelio sąvokos judejimo procese atvaizdavima gretinamuosiuose pasakojamojo tipo tekstuose, išverstuose iš anglu i rumunu kalbą. Keliama hipotezè, kad rumunu kalbai galètu būti suteikiamas mišrus tipologinis statusas, priskiriant ja "išskaidytu" kalbu klasei. Daroma prielaida, kad, pirmiausia, ši kalba turi daugiau judejjimo būda išreiškiančiu veiksmažodžiu nei galimai yra VLs tipo kalbu atveju. Pateikiamos alternatyvios SLs ir VLs tipo kalbu kategorijos, atitinkamai turinčios daug ir mažai būdo reiškimo veiksmažodžiu (MmV). Antra, nereikètu atmesti galimybès panaudoti kompleksinę kelio, kaip MmV satelito, savoką - ypač ribu peržengimą. Tai padètu nustatyti kalbos tipologinę klasę (pvz. a țâșnit de după perdea (lit. rushed from behind the curtain) - 'rushed out from behind the curtain'; a lunecat de pe acoperiș (lit. slipped from on the roof) - 'slipped from the roof'). Šiuo atžvilgiu straipsnyje siekiama išanalizuoti antrojo prielinksnio prigimti.

Pagrindinès sąvokos: tipologija, judejjimo procesas, ribos peržengimas, būdo veiksmažodžiai, kelio veiksmažodžiai, anglu, rumunu. 